\title{
Phosphorus supplying capacities of soils previously fertilized with different rates of $P$
}

\author{
MARKKU YLI-HALLA \\ Kemira Oy, Espoo Research Centre, Luoteisrinne 2, \\ SF-02270 Espoo, Finland
}

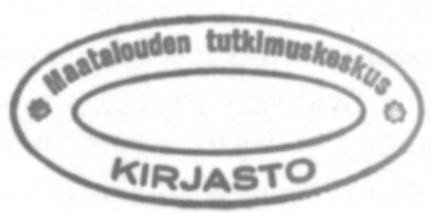

\begin{abstract}
The residual effect of repeated P fertilizer applications was studied in a material of 30 silty clay soil samples collected from an 11-year field experiment in which a total of $0,154,309,541$ or $696 \mathrm{~kg}$ P/ha had been applied in annual doses. Half of the experiment had been limed twice with $\mathrm{CaCO}_{3}(10$ tons/ha). In a pot experiment, six yields of Italian ryegrass were grown in soils taken from each plot, and the $\mathrm{P}$ uptake by the grass was determined. Soil $\mathrm{P}$ was extracted with water $\left(\mathrm{P}_{\mathrm{w}}\right)$ and $0.5 \mathrm{M}$ ammonium acetate-0.5 $\mathrm{M}$ acetic acid at pH $4.65\left(\mathrm{P}_{\mathrm{AAAC}}\right)$. Reversibly adsorbed $\mathrm{P}\left(\mathrm{P}_{\mathrm{i}}\right)$ was extracted by a new method in which $\mathrm{P}$ desorbing from the soil was collected in strips of filter paper impregnated with iron hydroxide. $\mathbf{P}$ uptake by pot-grown grass from soils fertilized with increasing rates of $\mathbf{P}$ in the field corresponded to $30,72,100$ and $112 \mathrm{~kg}$ larger quantities of $\mathrm{P}$ per hectare, compared to the soil not receiving $\mathbf{P}$ in the field experiment. The apparent utilization of residual fertilizer $\mathbf{P}$ ranged from $16 \%$ to $25 \%$. The reserve of potentially desorbable $\mathrm{P}$ in soil had been affected much more by the fertilizer applications than had $\mathrm{P}$ uptake by crops in the field. The ability of the three extraction methods $\left(\mathrm{P}_{\mathrm{w}}, \mathrm{P}_{\mathrm{i}}, \mathrm{P}_{\text {AAAc }}\right)$ to predict $\mathrm{P}$ uptake by pot-grown ryegrass was discussed. The $P_{i}$ method appeared to be well suited for assessment of potentially available $P$ reserves both in limed and unlimed soils.
\end{abstract}

Index words: water extraction, acid ammonium acetate extraction, reversibly adsorbed $\mathrm{P}$, pot experiment, liming

\section{Introduction}

Since soil testing was started in Finland in the 1950 s, the average of easily soluble $\mathrm{P}$, extracted with an ammonium acetate solution at $\mathrm{pH} 4.65\left(\mathrm{P}_{\mathrm{AAAc}}\right)$ (VUORINEN and MÄKITIE 1955), has increased from $5.4 \mathrm{mg} / \mathrm{dm}^{3}$ in $1955-60$ to $12.5 \mathrm{mg} / \mathrm{dm}^{3}$ in 1988 (КӒHÃRI et al. 1987, KÃHĀRI 1989), indicating accumula- tion of soluble residual P in soils. Recommendations for $\mathbf{P}$ fertilization in Finland are based on the results of field experiments in which the relationships between yield response to $\mathrm{P}$ fertilization and the quantities of $\mathrm{P}_{\mathrm{AAAc}}$ in the soil have been studied. Differing from fertilization recommendations, the actual quantity 
of potentially desorbable $\mathrm{P}$ (capacity factor) cannot be determined by methods such as AAAc or water extractions, which primarily reflect the concentration of $\mathrm{P}$ in the soil solution (intensity factor), because the relationship between the intensity and capacity factors of $\mathrm{P}$ is regulated, for example, by clay content and the contents of poorly crystalline $\mathrm{Al}$-oxide and $\mathrm{Fe}$-oxide. Neither can the reserves of potentially soluble $\mathrm{P}$ be estimated to be equal to the quantity of fertilizer $\mathrm{P}$ remaining in the soil, i.e. the difference between $P$ fertilization and uptake by the crop, because the solubility of residual $\mathrm{P}$ decreases over time. This phenomenon was recently exemplified in an 11-year field experiment on a silty clay soil (Yli-Halla 1989 b), where an annual P application which was double the quantity of $P$ uptake by the crop was needed to maintain the original level of $\mathrm{P}_{\mathrm{AAAC}}$ in the soil.

In principle, potentially desorbable $\mathrm{P}$ may be solubilized in a water extraction upon infinite solution-to-soil ratio (MADRID and PosNER 1979), but, in practice, procedures involving very wide extraction ratios are difficult to perform. Strongly dissolving solutions, on the other hand, may also extract practically inert $\mathrm{P}$ reserves. A new method (ZEE et al. 1987), based on the affinity for phosphate of freshly precipitated iron hydroxide, has been introduced for the extraction of reversibly adsorbed $\mathrm{P}$, and may be promising for the determination of soluble residual $\mathbf{P}$ as well. Intensive pot experiments have also been used to estimate the residual effect of $\mathrm{P}$ fertiliza- tion (Novais and Kamprath 1978, StefFens 1987).

In the present study, the P supplying capacity of soils fertilized with different rates of $P$ for 11 years was studied. The yield results of the field trial in which the current soil material originates have been published earlier (Yli-Halla 1989 b). In this paper, which is the second part of the study, the reserves of plant-available $\mathrm{P}$ remaining in the soil after the field experiment were determined in a pot experiment. Three extraction methods were also evaluated for their ability to differentiate between soils containing different quantities of residual $\mathrm{P}$, as well as to predict $\mathrm{P}$ uptake by ryegrass from the respective soils.

\section{Materials and methods}

The soil material consisted of 30 silty clay samples taken from plough layers $\left(A_{p}\right.$ horizons) of a field experiment in which the plots had been given different rates of P fertilization. Some chemical and physical characteristics of the soil samples, determined at the end of the field experiment, are presented in Table 1. The field experiment was conducted at Kotkaniemi experimental farm in Vihti, Southern Finland, from 1974 to 1985 . The sampled plots had been fertilized annually with $0,13 / 16,26 / 32,47 / 56$ or $60 / 72 \mathrm{~kg} \mathrm{P} / \mathrm{ha}$ in $1974-82 / 1983-85$. The phosphorus was given to the plots in NPK fertilizers, mainly in a water-soluble form. There were three blocks in the experiment. Half of each block

Table 1. Some physical and chemical characteristics of the experimental soils.

\begin{tabular}{|c|c|c|c|c|}
\hline \multirow[t]{2}{*}{ Characteristics } & \multicolumn{2}{|c|}{$\begin{array}{l}\text { Unlimed soils } \\
\qquad \mathrm{n}=15\end{array}$} & \multicolumn{2}{|c|}{$\begin{array}{l}\text { Limed soils } \\
\mathrm{n}=15\end{array}$} \\
\hline & mean & range & mean & range \\
\hline Clay, \% & 31 & $25-40$ & 31 & $25-37$ \\
\hline Silt, $\%$ & 35 & $30-37$ & 35 & $32-36$ \\
\hline Sand, $\%$ & 35 & $26-45$ & 34 & $24-43$ \\
\hline Organic $C, \%$ & 3.4 & $2.1-5.1$ & 3.4 & $2.4-5.5$ \\
\hline $\mathrm{pH}\left(\mathrm{H}_{2} \mathrm{O}\right)$ & 6.0 & $5.8-6.1$ & 6.6 & $6.4-7.1$ \\
\hline Oxalate-extr. $\mathrm{Fe}, \mathrm{mmol} / \mathrm{kg}$ & 85 & $76-91$ & 77 & $63-91$ \\
\hline Oxalate-extr. $\mathrm{Al}, \mathrm{mmol} / \mathrm{kg}$ & 64 & $52-86$ & 67 & $40-113$ \\
\hline
\end{tabular}


was limed in the spring of 1977 and of 1985 with $\mathrm{CaCO}_{3}$ (10 tons/hectare). The last liming took place four months before soil sampling. The results concerning the yields of the unlimed plots have been presented in detail in a previous paper (YLI-HaLLA 1989 b), in which the current trial was referred to as ' $\mathrm{Ex}$ periment B'. Some data of the P status of the soil were also included. In terms of crop yields, there was no difference between the limed and unlimed plots within a given $\mathrm{P}$ rate. During the 11 experimental years, the total quantities of $\mathrm{P}$ fertilization applied, the quantities of $P$ carried away in the harvested crop as well as the $\mathrm{P}$ balances are presented in $\mathrm{Ta}$ ble 2 .

At the end of the field experiment, the plots were sampled and the soils were extracted with a solution containing $0.5 \mathrm{M}$ ammonium acetate and $0.5 \mathrm{M}$ acetic acid at $\mathrm{pH} 4.65$

Table 2. Quantities of $\mathbf{P}$ added to the soil and taken up by the harvested crop as well as $\mathrm{P}$ balances of the soil at the end of an 11-year field experiment.

\begin{tabular}{|c|c|c|c|c|c|}
\hline \multirow{2}{*}{$\begin{array}{l}\text { Treatment } \\
\mathrm{kg} \mathrm{P} / \mathrm{ha} / \text { year }\end{array}$} & \multirow{2}{*}{$\begin{array}{c}\text { Total P } \\
\text { fertilization } \\
\mathrm{kg} \mathrm{P} / \mathrm{ha}\end{array}$} & \multicolumn{2}{|c|}{ P uptake, $\mathrm{kg} / \mathrm{ha}$} & \multicolumn{2}{|c|}{ P balance, $\mathrm{kg} / \mathrm{ha}$} \\
\hline & & unlimed & limed & unlimed & limed \\
\hline 0 & - & 153 & 156 & -153 & -156 \\
\hline $13 / 16$ & 154 & 162 & 165 & -8 & -11 \\
\hline $26 / 32$ & 309 & 171 & 170 & 138 & 139 \\
\hline $47 / 56$ & 541 & 162 & 166 & 379 & 375 \\
\hline $60 / 72$ & 696 & 174 & 168 & 522 & 528 \\
\hline
\end{tabular}

Table 3. Quantities of $P$ extracted with water $\left(P_{w}\right)$ and acid ammonium oxalate $\left(P_{\text {AAAc }}\right)$ as well as the quantities of reversibly adsorbed $\mathrm{P}\left(\mathrm{P}_{\mathrm{i}}\right)$ in soils fertilized with different quantities of $\mathrm{P}$ for 11 years. ${ }^{1}$

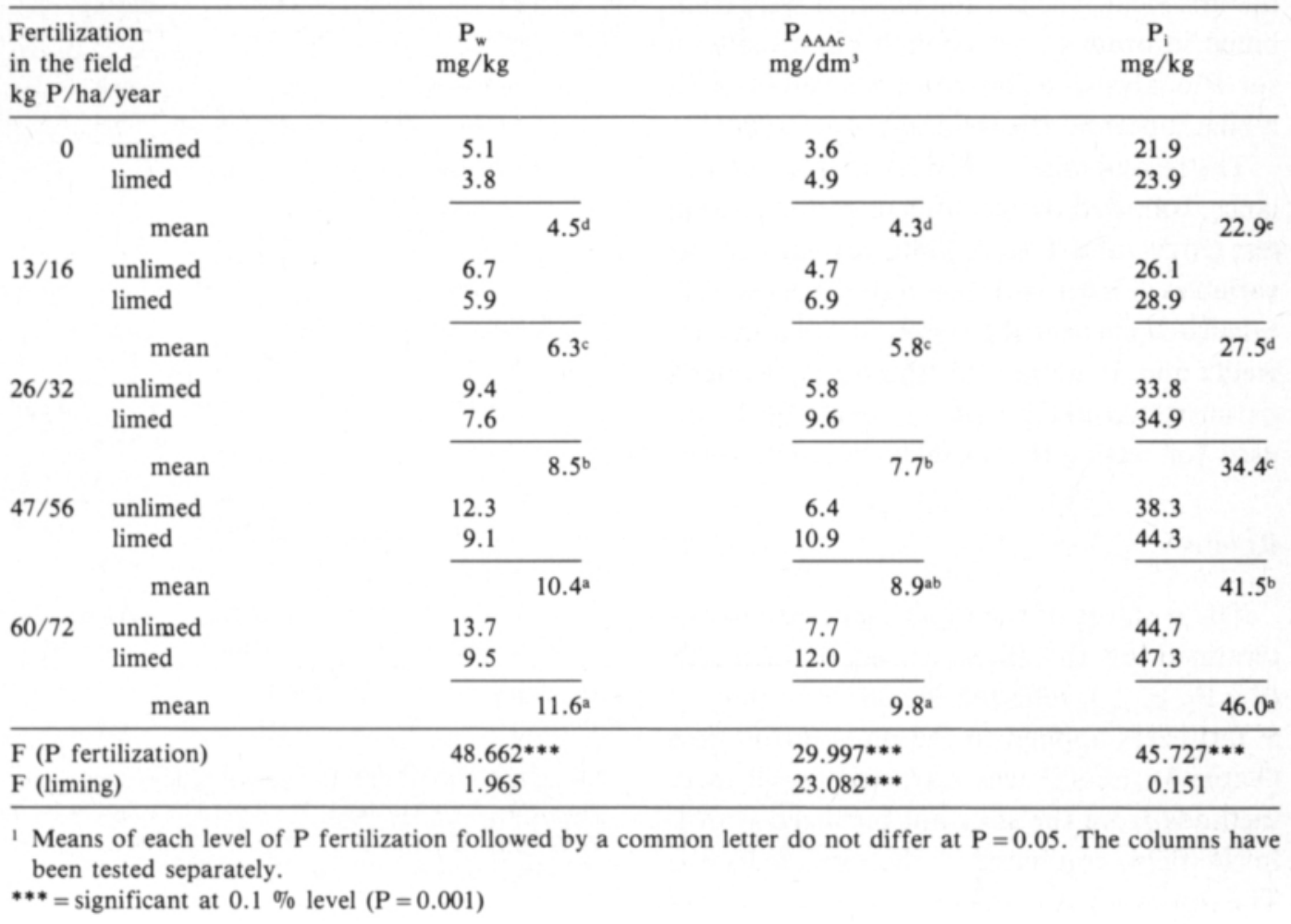


(P $\left.P_{\text {AAAC }}\right)$ (Vuorinen and MäKITIE 1955), and with deionized water (HARTIKAINEN 1982). Further, reversibly adsorbed $\left(\mathrm{P}_{\mathrm{i}}\right)$ was extracted by a method in which $\mathrm{P}$ desorbing from the soil is trapped by stips of filter paper impregnated with freshly precipitated iron hydroxide (Zee et al. 1987, Yli-Halla 1989 a). All soil analyses were performed as duplicate.

The soils were used in a pot experiment in which six yields of Italian ryegrass (Lolium multiflorum, Lam.) were grown in $0.8 \mathrm{~kg}$ of soil. There were two pots from each soil in the experiment. All other nutrients except $P$ were mixed into the soil at the beginning of the experiment in nutrient solutions. The compounds and quantities $(\mathrm{mg} / \mathrm{kg}$ ) used were as follows: $\mathrm{N} 300$ as $\mathrm{NH}_{4} \mathrm{NO}_{3}, \mathrm{~K} 250$ as $\mathrm{KCl}$, Mg 38 as $\mathrm{MgSO}_{4} \cdot 7 \mathrm{H}_{2} \mathrm{O}$, S 50 mainly as $\mathrm{MgSO}_{4} \cdot 7 \mathrm{H}_{2} \mathrm{O}, \mathrm{Zn} 3$ as $\mathrm{ZnSO}_{4} \cdot 7 \mathrm{H}_{2} \mathrm{O}, \mathrm{Cu}$ 3 as $\mathrm{CuSO}_{4} \cdot 5 \mathrm{H}_{2} \mathrm{O}$, Mn 4 as $\mathrm{MnSO}_{4} \cdot 4 \mathrm{H}_{2} \mathrm{O}$, Fe 3 as $\mathrm{FeSO}_{4} \cdot 7 \mathrm{H}_{2} \mathrm{O}$, B 0.5 as $\mathrm{H}_{3} \mathrm{BO}_{3}$ and Mo 0.5 as $\mathrm{Na}_{2} \mathrm{MoO}_{4} \cdot 2 \mathrm{H}_{2} \mathrm{O}$. For the successive crops, $\mathrm{N}, \mathrm{K}, \mathrm{Mg}$ and $\mathrm{S}$ fertilizer solutions were pipetted onto the surface of the pots, the quantities of nutrients being the same as for the first yield. The 5th and 6th yield were combined in order to get enough plant material for P analysis, performed by a vanado-molybdate method (SAARI and PAASO 1980).

The results were studied by analyses of variance, followed by the Student-Neuman-Keul test (STEel and Torrie 1980) for each of the variables. Linear correlation coefficients were calculated between the results of soil analyses, yield, and P uptake by the grass. Fisher's z-transformation test (RANTA et al. 1989) was used for testing the correlation coefficients.

\section{Results}

The P status of the experimental soils, determined by the three extraction methods $\left(\mathrm{P}_{\mathrm{w}}, \mathrm{P}_{\mathrm{i}}, \mathrm{P}_{\mathrm{AAAc}}\right)$, reflected the different rates of $\mathrm{P}$ fertilizers applied to the plots in the field (Table 3). Less $P$ was extracted by all three methods from the soils not fertilized with $\mathrm{P}$ in the field, compared to the fertilized soils. The soils annually receiving either of the two highest doses of P did not differ from one another in terms of $\mathrm{P}_{\mathrm{AAAc}}$ and $\mathrm{P}_{\mathrm{w}}$ even though the soils proved to contain different amounts of reversibly adsorbed $\mathrm{P}\left(\mathrm{P}_{\mathrm{i}}\right)$. In the unlimed soils, the quantities of $\mathrm{P}_{w}$ were greater than those of $\mathrm{P}_{\mathrm{AAAc}}$ at all levels of previous $\mathrm{P}$ fertilization, but the opposite was observed in the limed soils. The quantities of $\mathrm{P}_{\mathrm{i}}$ were four to five times greater than those of $\mathrm{P}_{w}$ and $\mathrm{P}_{\mathrm{AAAc}}$. In the unlimed soils, the results of the $\mathrm{P}_{\mathrm{w}}, \mathrm{P}_{\mathrm{i}}$ and $\mathrm{P}_{\mathrm{AAAc}}$ methods correlated closely with each other, but in the limed soils the results of the $\mathrm{P}_{\mathrm{AAAc}}$ method correlated only fairly with those of the $\mathrm{P}_{\mathrm{i}}$ method. The linear correlation coefficients (r) were as follows:

\begin{tabular}{|c|c|c|c|}
\hline \multicolumn{2}{|c|}{ Unlimed } & \multicolumn{2}{|c|}{ Limed } \\
\hline $\mathrm{P}_{\mathrm{i}}$ & $\mathrm{P}_{\mathrm{AAAC}}$ & $\mathrm{P}_{\mathrm{i}}$ & $\mathrm{P}_{\mathrm{AAAC}}$ \\
\hline $0.96 * * *$ & $0.95^{* * *}$ & $0.91 * * *$ & $0.88^{* * *}$ \\
\hline & $0.95^{* * *}$ & & $0.70^{* *}$ \\
\hline
\end{tabular}

Table 4. Quantities of dry matter produced and P taken up by ryegrass in a pot experiment.'

\begin{tabular}{|c|c|c|c|}
\hline \multicolumn{2}{|c|}{$\begin{array}{l}\text { Fertilization } \\
\text { in the field } \\
\mathrm{kg} \mathrm{P} / \mathrm{ha} / \text { year }\end{array}$} & \multirow{2}{*}{$\begin{array}{c}\begin{array}{c}\text { Dry matter } \\
\text { yield } \\
\mathrm{g} / \mathrm{kg} \text { of soil }\end{array} \\
36.9\end{array}$} & $\begin{array}{c}\text { P uptake } \\
\mathrm{mg} / \mathrm{kg} \\
\text { of soil }\end{array}$ \\
\hline \multirow[t]{3}{*}{0} & unlimed & & 39.4 \\
\hline & limed & 47.8 & 48.4 \\
\hline & mean & $42.3^{c}$ & $43.9^{\mathrm{d}}$ \\
\hline \multirow[t]{3}{*}{$13 / 16$} & unlimed & 45.0 & 51.4 \\
\hline & limed & 50.8 & 60.6 \\
\hline & mean & $47.9^{b}$ & $56.0^{\circ}$ \\
\hline \multirow[t]{3}{*}{$26 / 32$} & unlimed & 50.1 & 68.2 \\
\hline & limed & 56.0 & 77.3 \\
\hline & mean & $53.0^{\mathrm{a}}$ & $72.8^{b}$ \\
\hline \multirow[t]{3}{*}{$47 / 56$} & unlimed & 52.5 & 77.7 \\
\hline & limed & 60.0 & 89.6 \\
\hline & mean & $56.2^{\mathrm{a}}$ & $83.7^{\mathrm{a}}$ \\
\hline \multirow[t]{3}{*}{$60 / 72$} & unlimed & 56.5 & 87.8 \\
\hline & limed & 60.1 & 89.3 \\
\hline & mean & $58.3^{\mathrm{a}}$ & $88.6^{\mathrm{a}}$ \\
\hline \multirow{2}{*}{\multicolumn{2}{|c|}{$\begin{array}{l}\mathrm{F} \text { (P fertilization) } \\
\mathrm{F} \text { (liming) }\end{array}$}} & $20.060 * * *$ & $71.657^{* * *}$ \\
\hline & & $5.511^{*}$ & 0.687 \\
\hline
\end{tabular}

1 Means of each level of $\mathrm{P}$ fertilization followed by a common letter do not differ at $\mathbf{P}=0.05$. The columns have been tested separately.

* = significant at $5 \%$ level $(\mathrm{P}=0.05)$

*** = significant at $0.1 \%$ level $(\mathrm{P}=0.001)$ 
Yield 1

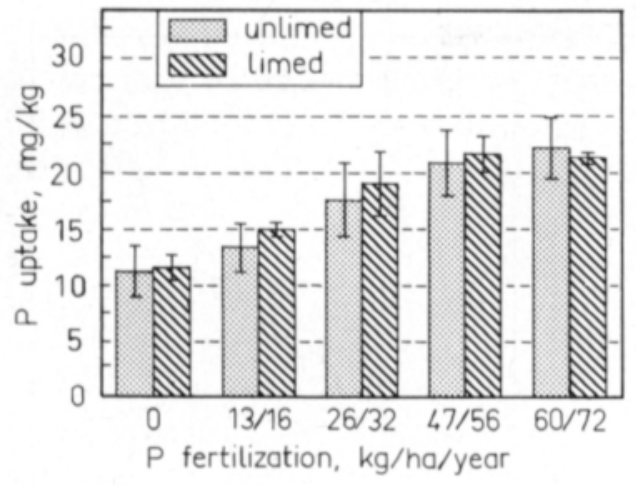

Yield 3

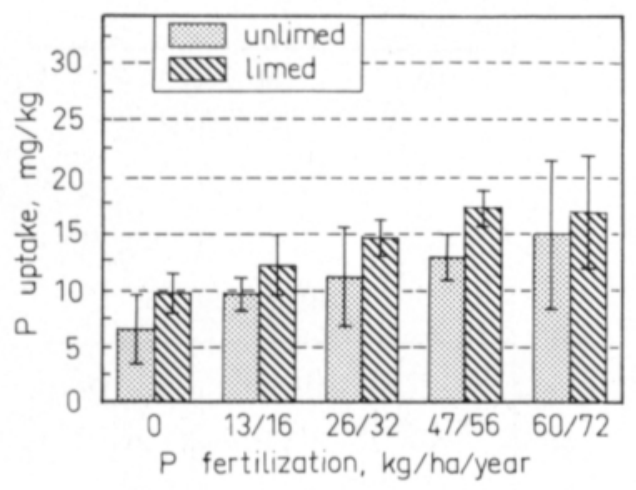

Yield $5+6$

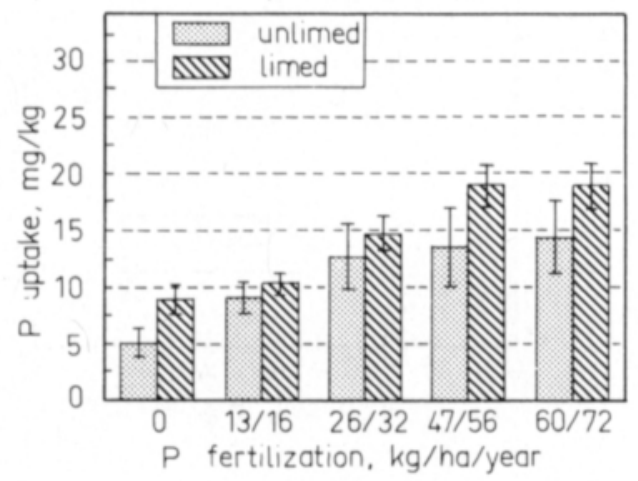

Yield 2

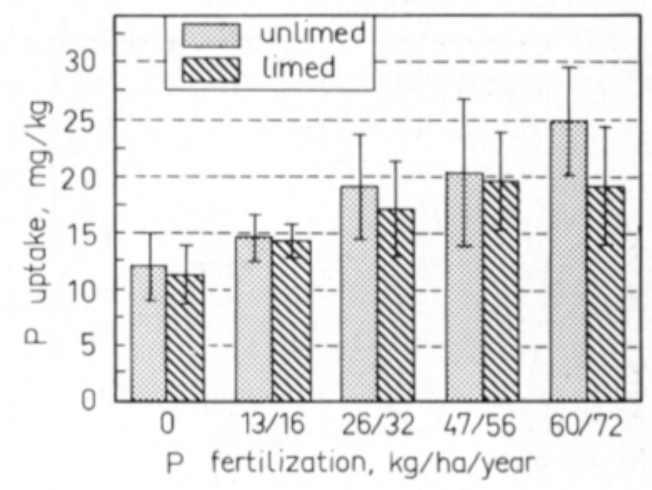

Yield 4

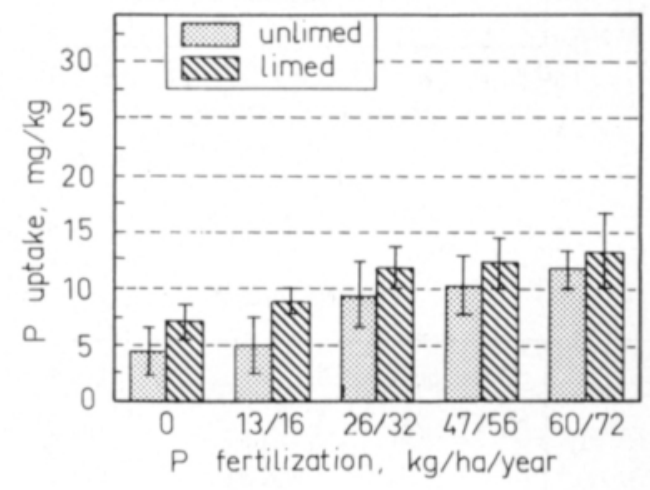

Sum of yields

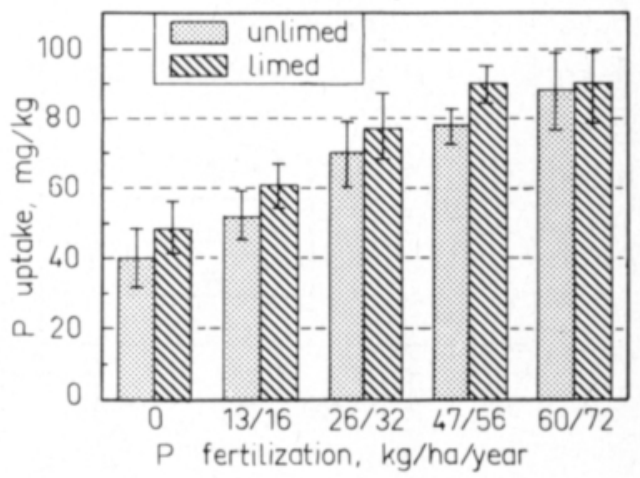

Fig. 1. Uptake of $\mathrm{P}$ by ryegrass in the pot experiment from soils fertilized with different rates of $\mathrm{P}$ in the field for 11 years. The confidence limits at the $95 \%$ level are shown.

In the pot experiment, the dry matter yields of ryegrass were the higher, the more heavily the soils had been fertilized with $\mathrm{P}$ in the previous field experiment (Table 4). The limed soils produced, on the average, $16 \%$ more dry matter than did the unlimed ones. $\mathrm{P}$ concen- tration of the grass, which in the first yield ranged from 1.0 to $1.7 \mathrm{~g} / \mathrm{kg}$, was also in accordance with the concentration of easily soluble $\mathrm{P}$ in the soil. In the combined plant material of the 5th and 6th yield, the $\mathrm{P}$ concentration of all grass samples remained below 
unlimed soils

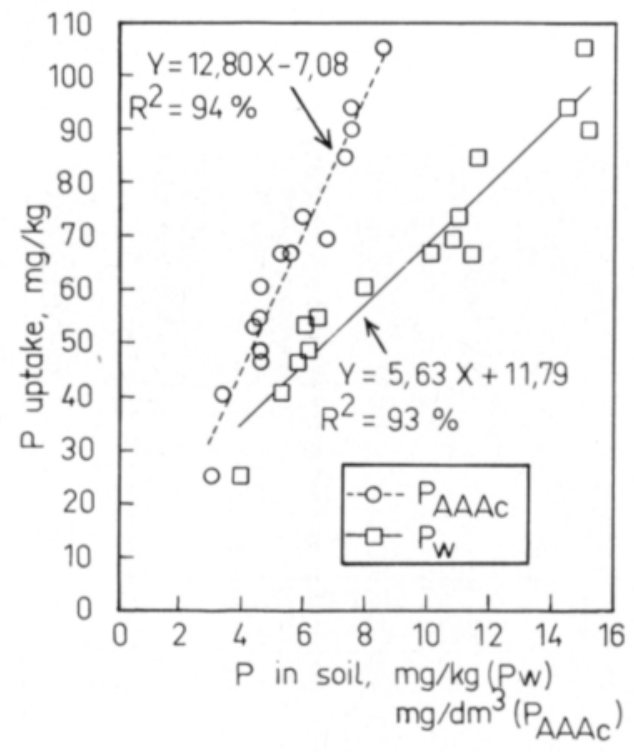

limed soils

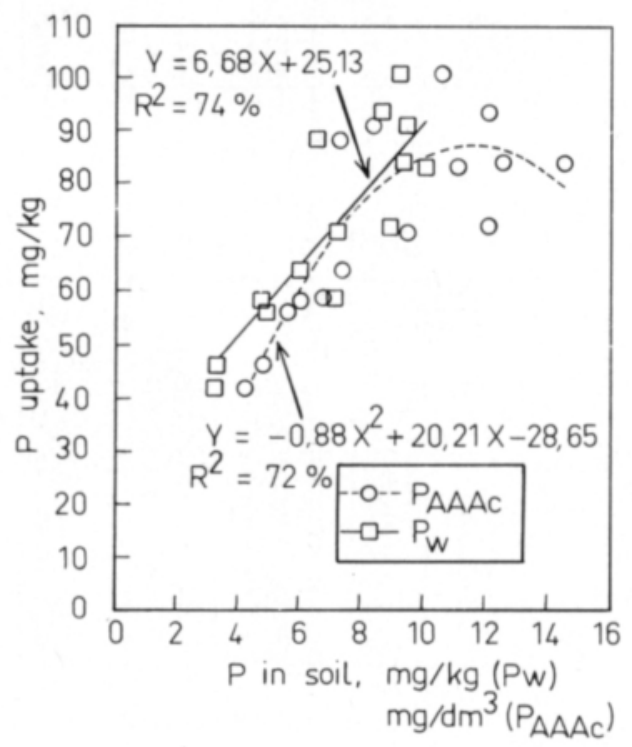

unlimed soils

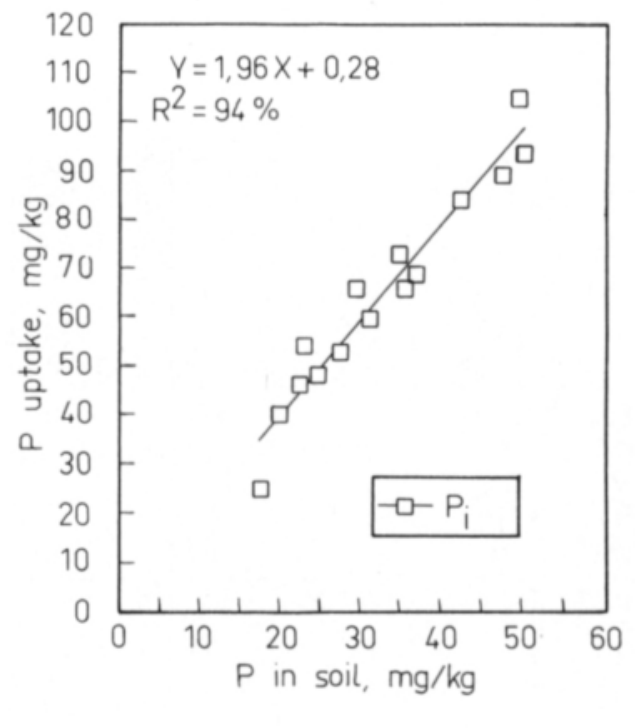

limed soils

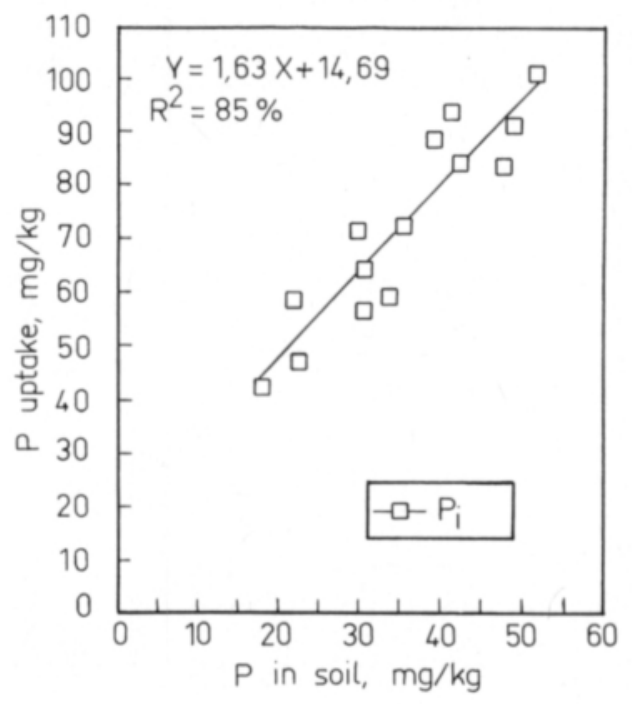

Fig. 2. Relationships between $P$ uptake by pot-grown ryegrass and the quantities of $P$ extracted with water $\left(P_{w}\right)$ and acid ammonium acetate $\left(\mathrm{P}_{\text {AMAC }}\right)$ and the quantities of reversibly adsorbed $\mathrm{P}\left(\mathrm{P}_{\mathrm{i}}\right)$ in limed and unlimed soils.

$1.0 \mathrm{~g} / \mathrm{kg}$, indicating a severe shortage of $P$. Thus, the reserves of plant-available $P$ were practically exhausted by the end of the pot experiment. The differences in the $\mathrm{P}$ supplying capacity of the soils were clear in every ryegrass yield (Fig. 1). Total $\mathrm{P}$ uptake by ryegrass tops (Table 4) in the soils fertilized in the field with either of the two highest doses of $\mathrm{P}$ was approximately double the $\mathrm{P}$ uptake in the soil not receiving any $\mathrm{P}$ fertilization in the field. P uptake from the limed soils was, on the average, $18 \%$ greater than that from 
the unlimed ones.

In the unlimed soils, the quantities of $\mathrm{P}_{w}$, $P_{i}$ and $P_{A A A c}$ correlated closely with the uptake of $\mathrm{P}$ by the plants throughout the experiment. In the limed soils, both the $\mathrm{P}_{\mathrm{w}}$ and the $\mathrm{P}_{\mathrm{AAAc}}$ method failed to predict $\mathrm{P}$ uptake as accurately as they did in the unlimed soils. The relationships between the sum of $\mathrm{P}$ uptake by the six yields and $\mathrm{P}_{\mathrm{w}}, \mathrm{P}_{\mathrm{i}}$ and $\mathrm{P}_{\mathrm{AAAc}}$ are shown in Fig. 2. In addition, the data of the limed and unlimed soils were combined and studied by correlation analyses. According to the z-transformation test, the results of the $\mathrm{P}_{\mathrm{i}}$ method were more closely $(\mathrm{P}=1 \%)$ correlated $\left(\mathrm{r}=0.95^{* * *}\right)$ with $\mathrm{P}$ uptake than were those of $\mathrm{P}_{\mathrm{w}}\left(\mathrm{r}=0.78^{* * *}\right)$ and $\mathrm{P}_{\mathrm{AAAc}}(\mathrm{r}=$ $\left.0.78^{* * *}\right)$.

Total $\mathrm{P}$ uptake by ryegrass was transformed from milligrams per kilogram of soil to kilograms per hectare by assuming that the plough layer of one hectare consists of $2500000 \mathrm{~kg}$ of soil. Further, the difference in P uptake in the pot experiment, owing to the fertilization treatments given in the field, was calculated as the mean of the limed and unlimed soil at each $P$ rate. In the pot experiment, $P$ uptake by the grass from the soils fertilized with $13 / 16,26 / 32,47 / 56$ and $60 / 72 \mathrm{~kg} \mathrm{P} / \mathrm{ha}$, respectively, corresponded to $30,72,100$ and $112 \mathrm{~kg}$ larger quantities of $\mathrm{P}$ per hectare than that taken up from the soil not fertilized with $\mathbf{P}$ during the field experiment. Based on these differences and $\mathrm{P}$ balances (Table 2), it is possible to estimate roughly how much of that phosphorus which made up the difference in soil $\mathrm{P}$ status in the field was utilized by ryegrass in the pot experiment. The following equation was used:

$$
\mathrm{U}=\frac{\left(\mathrm{P}_{\mathrm{xp}}-\mathrm{P}_{\mathrm{Op}}\right) \times 2500000}{\mathrm{P}_{\mathrm{xf}}-\mathrm{P}_{\mathrm{Of}}} \times 100
$$

where

$\mathrm{U}=$ utilization $(\%)$

$\mathrm{P}_{\mathrm{xp}}=\mathrm{P}$ uptake $(\mathrm{mg} / \mathrm{kg})$ by pot-grown ryegrass at a given $\mathrm{P}$ fertilization level (Table 4)

$\mathrm{P}_{\mathrm{Op}}=\mathrm{P}$ uptake $(\mathrm{mg} / \mathrm{kg})$ by pot-grown ryegrass from the soil not fertilized with

$\mathrm{P}$ during the field experiment (Table 4) $\mathrm{P}_{\mathrm{xf}}=\mathrm{P}$ balance $(\mathrm{kg} / \mathrm{ha})$ at a given level of $\mathrm{P}$ fertilization at the end of the field experiment (Table 2)

$\mathrm{P}_{\mathrm{Of}}=\mathrm{P}$ balance $(\mathrm{kg} / \mathrm{ha})$ after the field experiment in the soil not fertilized with $\mathrm{P}$ (Table 2)

Concerning $\mathrm{P}$ uptake by the pot-grown ryegrass, the differences between the soils fertilized with $\mathrm{P}$ and the unfertilized one corresponded to $21 \%, 25 \%, 19 \%$ and $16 \%$ of the difference in the calculated $\mathrm{P}$ balances of the soils at $\mathrm{P}$ rates of $13 / 16,26 / 32,47 / 56$ and $60 / 72 \mathrm{~kg} \mathrm{P} / \mathrm{ha}$, respectively. These percentages thus represent the apparent utilization of the difference in P status created in the field by the fertilizer applications.

\section{Discussion}

The pot experiment showed that the different rates of $\mathrm{P}$ fertilization applied during the previous field experiment had a considerable residual effect and had obviously greatly influenced the pool of easily soluble $\mathrm{P}$ of the soil, as was also suggested by the results of the three extraction methods $\left(\mathrm{P}_{\mathrm{w}}, \mathrm{P}_{\mathrm{i}}, \mathrm{P}_{\mathrm{AAAc}}\right)$. $\mathrm{P}$ uptake by the pot-grown ryegrass corresponded to the range of 110 to $220 \mathrm{~kg} \mathrm{P} / \mathrm{ha}$ in a plough layer consisting of $2500000 \mathrm{~kg}$ of soil, revealing the considerable reserve of potentially desorbable $\mathrm{P}$ in the soil. The cereal crops grown in the field experiment had taken up a total of 155 to $171 \mathrm{~kg} \mathrm{P} / \mathrm{ha}$ during the 11 experimental years (YLI-Halla 1989 b), and had thus responded only slightly to the wide range of plant-available $P$ reserves in the plots even though the experimental soil was only average in $\mathrm{P}$ status, compared with the means of $\mathrm{P}_{w}, \mathrm{P}_{\mathrm{i}}$ and $\mathrm{P}_{\text {AAAc }}$, presented in other studies (e.g. HartiKainen 1982, КӒHÄRI 1987, Yli-Halla 1989 a). It should be pointed out that the estimates for the maximum amounts of desorbable $\mathrm{P}$ obtained in the pot experiment must not be considered absolute values because the actual result of $P$ uptake depends, for example, on the duration 
and intensity of the pot experiment. Yet, the present results give some idea of the magnitude of potentially desorbable $P$ reserves contained in a cultivated field.

According to the $\mathrm{P}$ balances, the soils fertilized annually with $26 / 32,47 / 56$ or $60 / 72 \mathrm{~kg}$ $\mathrm{P} /$ ha had been enriched with $\mathrm{P}$ during the previous field experiment. In the soil not receiving $P$, the reserves of $P$ had been depleted, while no net change had occurred in the soil fertilized annually with 13/16 kg $\mathrm{P} / \mathrm{ha}$. In the pot experiment, apparently only $16-25 \%$ of that phosphorus making up the difference between the soils fertilized and not fertilized with $\mathrm{P}$ allowed itself to be taken up by ryegrass tops, even though the plants eventually suffered from extreme P shortage. In addition to the quantity of $\mathrm{P}$ in the plant tops, an undefined quantity of $\mathrm{P}$ was contained in ryegrass roots. However, the bulk of residual $\mathrm{P}$ is likely to have been immobilized in inorganic and organic forms unavailable to plants, because residual fertilizer $\mathrm{P}$ has considerably been recovered as inorganic $\mathrm{P}$ in the soil (Yli-Halla 1989 b). It may be supposed that recent fertilizer residues would have been more soluble than those added to the soil in the early years of the field experiment. Thus the current estimate represents the average maximum utilization of residual $P$ accumulating in the soil during 11 years.

The results of the $\mathrm{P}_{w}, \mathrm{P}_{\mathrm{i}}$ and $\mathrm{P}_{\mathrm{AAAc}}$ methods predicted accurately the differences in $\mathrm{P}$ uptake by ryegrass in the unlimed soils, and so did those of $\mathrm{P}_{\mathrm{i}}$ in the limed ones. These correlation coefficients were even higher than those obtained between the same indices and $\mathrm{P}$ uptake by ryegrass in a previous study (Yli-Halla 1990), in which the material consisted of mineral soils taken from 32 fields. The closer correlations in the present study between soil analysis and plant $\mathrm{P}$ uptake are probably due to the more homogeneous material as far as soil properties other than $\mathrm{P}$ sta- tus are concerned.

Increases of electrical conductivity and exchangeable $\mathrm{Ca}$ are factors known to reduce the quantities of $\mathrm{P}$ extracted with water (HARTIKAINEN 1990). Probable changes of these two soil properties, attributable to liming in the current study, may be the principal reasons for the lower values of $\mathrm{P}_{\mathrm{w}}$ in the limed soil, compared to the unlimed soils fertilized with the same $P$ rate. Contrary to the change in $\mathrm{P}_{\mathrm{w}}$, the $\mathrm{P}$ uptake by pot-grown grass was slightly greater from the limed plots. Therefore, the present study, in which the P supply was the primary factor limiting growth, suggest that the results of $P_{w}$ may be vulnerable to factors other than the actual P status of the soil. On the other hand, the results of the $\mathrm{P}_{\mathrm{AAAc}}$ method were increased by liming relatively more than was the uptake of $\mathrm{P}$ by the grass, suggesting that the $\mathrm{P}_{\mathrm{AAAc}}$ method may overestimate reserves of plant-available $P$ in recently limed soils, as has been argued by HARTIKAINEN (1989).

Information is accumulating that $\mathrm{P}_{\mathrm{i}}$ is a good indicator of the soil reserves of plantavailable $\mathrm{P}$, modified by $\mathrm{P}$ fertilization and liming. Earlier, MenON et al. (1989), in a pot experiment, showed that the results of the $P_{i}$ method correlated closely with $\mathrm{P}$ uptake by maize from four soils fertilized with different rates of Florida rock phosphate and triple superphosphate. In the current study, this method was well able to differentiate between soils containing varying amounts of residual $\mathrm{P}$ which originated in easily soluble $\mathrm{P}$ fertilizers applied to the soil over a decade. Further, the $\mathrm{P}_{\mathrm{i}}$ method was able to predict $\mathrm{P}$ uptake of ryegrass accurately from limed as well as from unlimed soils. The $\mathrm{P}_{\mathrm{i}}$ method may provide at least a semi-quantitative measure for the reserves of plant-available $P$ and means for studying the residual effect of $\mathrm{P}$ fertilization. 


\section{References}

Hartikainen, H. 1982. Water soluble phosphorus in Finnish mineral soils and its dependence on soil properties. J. Scient. Agric. Soc. Finl. 54: 89-98.

- 1989. Evaluation of water and ammonium acetate tests as indices for available $\mathrm{P}$ in limed soils. J. Agric. Sci. Finl. 61: 1-6.

- 1990. Effect of cation species on the desorption of phosphorus in soils treated with carbonate. Z. Pflanzenernähr. Bodenk. 152: 435-439.

KĀhā̌rı, J., MăntYlahtı, V. \& RannikKo, M. 1987. Suomen peltojen viljavuus 1981-1985. 105 p. Helsinki.

- 1989. Suomen peltojen viljavuuden kehittyminen vuosina 1986-1988. 11 p. Helsinki.

Madrid, L. \& Posner, A.M. 1979. Desorption of phosphate from goethite. J. Soil Sci. 30: 697-708.

Menon, R.G., Hammond, L.L. \& Sissingh, H.A. 1989. Determination of plant-available phosphorus by the iron oxide impregnated filter paper $\left(\mathrm{P}_{\mathrm{i}}\right)$ soil test. Soil Sci. Soc. Amer. J. 53: 110-115.

Novais, R. \& Kamprath, E.J. 1978. Phosphorus supplying capacities of previously heavily fertilized soils. Soil Sci. Soc. Amer. J. 42: 931-935.

Ranta, E., Rita, H. \& Koukı, J. 1989. Biometria. 2nd ed. Helsinki. 569 p.

SAARI, E. \& PAAso, A. 1980. Mineral element composition of Finnish foods. II. Analytical methods. Acta

\section{SELOSTUS}

\section{Fosforilannoituksen jälkivaikutus intensiivisessä astiakokeessa}

\section{Markku Yli-Halla}

\section{Kemira Oy, Espoon tutkimuskeskus, Luoteisrinne 2, 02270 Espoo}

Kolmenkymmenen hiuesavimaan P-tilaa tutkittiin astiakokeessa sekä kemiallisin analyysein. Näytteet oli otettu Vihdissă tehdystả kenttäkokeesta, jossa oli 11 vuoden aikana annettu NPK-lannoitteissa fosforia yhteensă 0, 154, 309,541 tai $696 \mathrm{~kg} / \mathrm{ha}$. Puolet kokeesta oli kalkittu kahdesti $\mathrm{CaCO}_{3}$ :lla (10 t/ha). Astiakokeessa kasvatettiin kuusi satoa Italian raiheinaaă, mikă lähes ehdytti maassa olleet kasveille käyttơkelpoisen P:n varat. Fosforilla lannoitetussa maissa kasvaneen raiheinăn yhteensă ottamat P-maaărăt vastasivat $30,72,100$ ja $112 \mathrm{~kg}$ suurempia $\mathrm{P}$-maaăriă hehtaaria kohti kuin $\mathrm{P}$-otto niistă maista, joita ei ollut lannoitettu fosforilla. Maahan kenttăkokeen aikana kertyneen P:n hyväksikäyttőaste vaihteli eri lannoitustasoilla $16 \%$ :sta $25 \%$ :iin. Kenttăkokeessa annetulla P-lannoituksella oli ollut merkittăvămpi vaikutus
Agric. Scand. Suppl. 20: 80-89.

Steel, R.G.D. \& Torrie, H.J. 1980. Principles and procedures of statistics. A biometrical approach. 633 p. 2nd Ed. Singapore.

STEFFENS, D. 1987. Einfluss langjähriger Düngung mit verschiedenen Phosphatdüngerformen auf die Phosphatverfügbarkeit in der Rhizosphäre von Raps. Z. Pflanzenernähr. Bodenk. 150: 75-80.

Vuorinen, J. \& MÃKıtıe, O. 1955. The method of soil testing in use in Finland. Agrogeol. Publ. 63. 44 p.

YLI-HaLlA, M. 1989 a. Reversibly adsorbed P in mineral soils of Finland. Commun. Soil Sci. Plant Anal. 20: 695-709.

- 1989 b. Effect of different rates of $\mathrm{P}$ fertilization on the yield and $\mathrm{P}$ status of the soil in two long-term field experiments. J. Agric. Sci. Finl. 61: 361-370.

- 1990. Comparison of a bioassay and three chemical methods for determination of plant-available $\mathrm{P}$ in cultivated soils of Finland. J. Agric. Sci. Finl. 62: 213219.

ZeE, S.E.A.T.M. van der, FoKKINK, L.G.T. \& RIEMSDIJK, W.H. van. 1987. A new technique for assessment of reversibly adsorbed phosphate. Soil Sci. Soc. Amer. J. 51: 599-604.

Ms received 29.5.1990 maan liukoisen P:n varoihin kuin aikanaan satojen pellolla ottamiin P-määriin. Viljavuusanalyysissä käytettăvăllă happamalla ammoniumasetaattiliuoksella ja vedellä maasta uuttuvat $\mathrm{P}$-mäărăt selittivăt kalkitsemattomissa maissa raiheinăn $\mathrm{P}$-oton vaihtelun tarkasti $\left(\mathrm{R}^{2}=\right.$ $0.94^{* * *}$ ja $0.93^{* * *}$ ) mutta kalkituissa maissa selitysasteet olivat hieman pienemmăt $\left(\mathrm{R}^{2}=0.72^{* * *}\right.$ ja $\left.0.74^{* * *}\right)$. Fosforin uuttoon kăytettiin lisăksi uutta menetelmaaa, jossa maasta liukeneva P sidotaan rautahydroksidilla kyllästettyyn suodatinpaperiin. Näin saadut tulokset ennustivat raiheinän $\mathrm{P}$-oton tarkasti kalkitsemattomista $\left(\mathrm{R}^{2}=\right.$ $\left.0.94^{* * *}\right)$ ja kalkituista $\left(\mathrm{R}^{2}=0.85 * * *\right)$ maista. Tällă menetelmăllă voidaan lisăksi määrittăă kasveille kăyttőkelpoisen P:n varoja kvantitatiivisemmin kuin asetaatti- tai vesiuutolla. 